\title{
Mycosphaerella musicola Identified as the Only Pathogen of the Sigatoka Disease Complex Present in Minas Gerais State, Brazil
}

Lahyre Izaete S. Gomes, Departamento de Fitopatologia, Universidade Federal de Viçosa, 36570-000 Viçosa, MG, Brazil; Greg W. Douhan, Department of Plant Pathology and Microbiology, University of California, Riverside, CA 92521; Líllian B. J. Bibiano, Luiz A. Maffia, and Eduardo S. G. Mizubuti, Departamento de Fitopatologia, Universidade Federal de Viçosa, 36570-000 Viçosa, MG, Brazil

\begin{abstract}
Gomes, L. I. S., Douhan, G. W., Bibiano, L. B. J., Maffia, L. A., and Mizubuti, E. S. G. 2013. Mycosphaerella musicola identified as the only pathogen of the Sigatoka disease complex present in Minas Gerais State, Brazil. Plant Dis. 97:1537-1543.

A thorough assessment of the distribution of Mycosphaerella spp. associated with banana in Minas Gerais State, Brazil, was conducted after Mycosphaerella fijiensis was first reported to occur in this region in 2005. From 2009 to 2011, 80 fields located in 20 municipalities including the same fields where the disease was first reported were sampled. A total of 800 samples of leaf tissue with symptoms similar to those of yellow or black Sigatoka diseases were examined, and 239 isolates were obtained. The identification of the fungi was based on morphological characters combined with DNA sequences obtained

after amplification with species-specific primers and phylogeny inferred from the internal transcribed spacer region of Mycosphaerella strains from banana. All 239 isolates were identified as Mycosphaerella musicola. The absence of $M$. fijiensis in the samples may have been due to misidentification of $M$. fijiensis or the displacement of $M$. fijiensis by $M$. musicola. It is now apparent that yellow Sigatoka caused by $M$. musicola is the prevailing leaf spot disease of bananas in Minas Gerais State and that regulatory/legislative control measures need to be revised based on our findings.
\end{abstract}

There are three leaf spot diseases of banana, commonly referred to as Sigatoka diseases, which are caused by three distinct species of Mycosphaerella. All species cause necrosis of leaf tissues that leads to defoliation and results in yield loss and premature or uneven ripening of the fruit. Sigatoka disease, known as yellow Sigatoka (YS), and black leaf streak disease (BLSD), also known as black Sigatoka (BS), are the two major leaf spot diseases that affect banana (Musa spp.) production in many tropical countries (34). Mycosphaerella musicola R. Leach ex J.L. Mulder (anamorph Pseudocercospora musae (Zimm.) Deighton) is the causal agent of YS and was the first Sigatoka foliar pathogen to be identified in 1902 (22). This pathogen is globally distributed and has caused crop losses wherever bananas are grown. In 1963, Mycosphaerella fijiensis M. Morelet (anamorph Pseudocercospora fijiensis (M. Morelet) Deighton) was identified as the causal agent of BS (30). $M$. fijiensis is not as widely distributed as $M$. musicola but due to its more aggressive nature has often displaced populations of $M$. musicola where the diseases co-occur (31). BS requires more intensive fungicide spray schedules to be effectively controlled (5). More recently, Mycosphaerella eumusae Crous \& Mourichon (anamorph Pseudocercospora eumusae Crous \& Mourichon) was reported in Asia (7), and this species' only known distribution is in Southeast Asia and parts of Africa (2).

Diagnosis of the Sigatoka diseases has traditionally been based on disease symptoms and morphology of the fungi associated with them $(15,18,29,34)$. However, all three Mycosphaerella species cause similar symptoms on banana leaves, which makes disease diagnosis very challenging. Moreover, due to the conserved teleomorph morphology in these Mycosphaerella species, no differences are detected even when perithecia or ascospores of the three species that infect banana are compared, which also makes diagnosis problematic (25). The major morphological differences between

Corresponding author: E. S. G. Mizubuti, E-mail: mizubuti@ufv.br

Accepted for publication 11 June 2013.

http://dx.doi.org/10.1094/PDIS-12-12-1212-RE

(C) 2013 The American Phytopathological Society
M. musicola, M. fijiensis, and M. eumusae are found in the anamorphic state (11). Conidiophores of $M$. musicola produce dense fascicles (sporodochia) on a dark brown or black stroma, while the conidiophores of $M$. fijiensis emerge singly or in small groups and sporodochia and stromata are absent (34). M. musicola is morphologically very similar to $M$. eumusae, and reports suggest that these two pathogens have commonly been misidentified (11). Sporodochia of M. eumusae have a similar shape to those of M. musicola showing epiphyllous sporodochia formed on dark brown substomatal stromata. Moreover, even when the pathogens are isolated from diseased tissues, identification of the various Mycosphaerella species is often difficult due to the overlapping and limited morphological characters (1). Reliable diagnosis is essential since all three diseases require unique management strategies to achieve satisfactory levels of control (21). M. fijiensis, for example, infects younger leaves on susceptible banana clones than those affected by $M$. musicola (22), and symptoms develop faster on banana infected with $M$. fijiensis and $M$. eumusae than with M. musicola (4). Therefore, chemicals need to be applied at different times, at different times of development of the host, and the number of applications needed to control each disease varies.

To overcome difficulties in disease diagnosis, polymerase chain reaction (PCR) methods have been developed to aid in proper species identification, as has been done for many other important plant pathogens $(1,16,21)$. Specifically, primers designed to amplify the internal transcribed spacer regions of rDNA have made it possible to differentiate $M$. musicola from $M$. fijiensis (21). More recently, species-specific PCR primers were developed based on the actin locus, and the development of TaqMan real-time quantitative PCR assay based on the beta-tubulin locus has made it possible to differentiate M. musicola, M. fijiensis, and M. eumusae (1).

In Brazil, YS occurs in all regions where banana is cultivated and BS was identified as occurring in Amazonas State in 1998 (28). BS spread rapidly to other areas throughout the North of Brazil, but has not been reported in the state of Tocantins. Afterward, the reports of occurrence of BS followed a North to South direction. The disease spread to the central-west regions (Mato Grosso and Mato Grosso do Sul) and was also reported to be present in the states of São Paulo and Minas Gerais, both in the southeast region of Brazil $(8,18,19)$, and in other states of the South region of Brazil (Fig. 1A). 
Banana is the second most important fruit crop in Minas Gerais State (20). However, the banana industry is currently facing difficulties due to the restrictions to commercialization after BS was officially reported to occur in the state $(8,14)$. M. fijiensis is a quarantine pathogen in some places in Brazil, and regulatory mechanisms prohibiting the movement of fruit and other plant materials are adopted to avoid the spread of the pathogen. This regulatory measure has resulted in serious economic hardship to some banana producing states, since fruit or plantlets produced in states where the disease has been recorded cannot be sold in states that are free of BS. In October 2006, one year after the first report of BS in Minas Gerais, a phytosanitary survey was conducted across the main banana regions of the state, and a regulatory document was issued by the Ministry of Agriculture of Brazil declaring some municipalities in the North, Northwest, Triângulo, and Vale do Jequitinhonha regions of Minas Gerais State as free from BS (23). After the abovementioned survey, no changes in the intensity of necrotic leaf spots affecting banana leaves were observed by growers in areas where BS was originally reported; nor has the usage of fungicide increased to control the disease. The disease is considered to be "under control" and probably restricted or absent in the areas where it was initially found. Apparently, in the state of Minas Gerais, putative epidemics of BS have not been as severe as those recorded in others regions of Brazil. The reasons for this controversial and questionable situation need clarification. Therefore, the objective of this work was to determine the causal agent(s) of the Sigatoka diseases in the main banana producing regions of Minas Gerais State, including those fields where BS was first reported.

\section{Materials and Methods}

Sampling scheme and isolate recovery. Leaf pieces $(20$ by 20 $\mathrm{cm}$ ) with symptoms of Sigatoka disease were collected, packed in plastic bags, and taken to the laboratory. After arriving at the laboratory, the samples were kept in the refrigerator until examination and pathogen isolation. Leaves with different symptoms (specks, streak, and spot) were collected from plants of different ages, but no adjacent plants were sampled in a field. Leaves from a minimum of 10 symptomatic plants were collected per field. For each sample, geographic coordinates were obtained using a portable GPS device (Magellan GPS Color TRAK, Magellan).

All samples were obtained from Minas Gerais State. Diseased plant material was collected from 80 fields in 20 municipalities in four regions of Minas Gerais State: South, North, Triângulo Mineiro (located to the West), and Zona da Mata (located to the southeast) (Fig. 1B; Table 1). The sampling started in January 2009 in the North region of Minas Gerais. From January 2010 until March 2011, a more intensive sampling was performed at different locations. Fields were chosen to represent the diversity of farming practices within the regions from small local farms ( 0.5 ha) with limited input to large (280 ha), well-managed banana plantations.
All samples were collected during the summer, which is the period of the year with intense rainfall and higher temperatures that favor the diseases. In some fields from Zona da Mata, South and North of Minas Gerais State, sampling was conducted in two different years (Table 1).

All leaf samples were first tentatively diagnosed by critically observing the Sigatoka disease symptoms in the field. The sampling procedure was biased toward the detection of BS as leaves with symptoms resembling those of BS were sought more carefully but all suspicious plants were sampled. A subset of the samples, mainly comprised of leaf pieces with BS-like symptoms, were subjected to more detailed analysis using microscopic characters. Lesions at different developmental stages (from streaks to spots) and from different parts of the leaf were inspected.

Under a compound microscope and using a sterile fine needle, conidia present on the abaxial surfaces of the symptomatic leaves were picked and transferred to water-agar medium. Single conidia were then taken from the water-agar medium and transferred to V8 agar medium ( $300 \mathrm{ml} \mathrm{V8} \mathrm{juice,} 3 \mathrm{~g}$ of $\mathrm{CaCO}_{3}$, and $20 \mathrm{~g}$ of agar per liter of medium). The single-spore isolates were incubated at $25^{\circ} \mathrm{C}$ under $12 \mathrm{~h}$ of daily white light regime for 10 days prior to examination and DNA extraction.

Discharge of ascospores from necrotic leaf material was used for leaf samples when no conidia were observed. Pieces of leaves with lesions were cut and were incubated in high humidity for $24 \mathrm{~h}$. After that, the leaves were soaked for 5 to $10 \mathrm{~min}$ in sterile water.

Table 1. Origin of the isolates of Mycosphaerella spp. collected from banana fields located in 20 municipalities of Minas Gerais State in 2009 to 2011

\begin{tabular}{llrl}
\hline Municipality & Region & Isolates & Year \\
\hline Pedralva & South & 3 & 2009 \\
Pouso Alegre & South & 1 & 2009 \\
Brazópolis & South & 11 & 2009 and 2011 \\
Cristina & South & 23 & 2009 and 2011 \\
Ipuiuna & South & 6 & 2011 \\
Itajubá & South & 18 & 2009 and 2011 \\
Maria da Fé & South & 18 & 2011 \\
Santa Bárbara do Tugúrio & Zona da Mata & 16 & 2010 \\
Piau & Zona da Mata & 18 & 2010 \\
Coronel Pacheco & Zona da Mata & 22 & 2010 and 2011 \\
Viçosa & Zona da Mata & 3 & 2009 and 2011 \\
Muriaé & Zona da Mata & 2 & 2011 \\
Araguari & Triângulo & 13 & 2010 \\
Monte Alegre de Minas & Triângulo & 1 & 2010 \\
Uberlândia & Triângulo & 8 & 2009 and 2010 \\
Matias Cardoso & North & 16 & 2011 \\
Nova Porteirinha & North & 9 & 2009 and 2011 \\
Verdelândia & North & 4 & 2009 \\
Jaíba & North & 28 & 2011 \\
Janaúba & North & 19 & 2011 \\
\hline
\end{tabular}
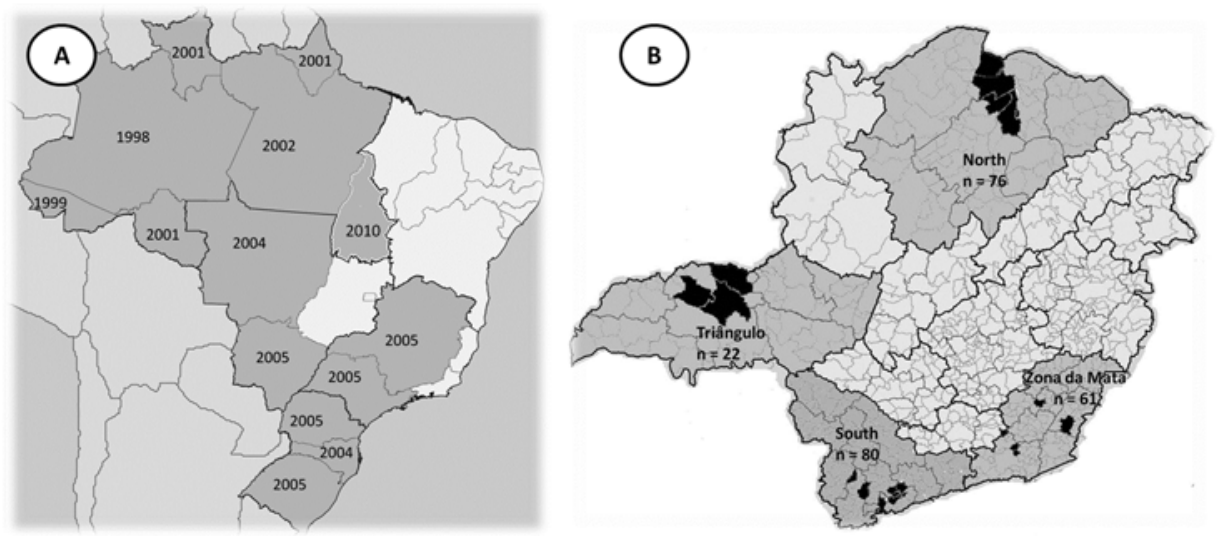

Fig. 1. A map of Brazil showing the distribution of states where black Sigatoka caused by Mycosphaerella fijiensis was detected (in gray) and the year of first report (A). Map of Minas Gerais State showing the different regions (in gray) and municipalities from where samples were collected (in black) (B). 
The pieces of tissue were fixed on filter paper and set on the internal part of the top of petri dishes with $2 \%$ water-agar for $2 \mathrm{~h}$ for ascospore discharge. Single ascospores ejected from perithecia were transferred to fresh V8 medium dishes using a fine needle and incubated at $25^{\circ} \mathrm{C}$ with $12 \mathrm{~h}$ of light for 15 days. After incubation, mycelial discs were transferred to V8 broth, and the DNA was extracted as described below. Pieces of tissue containing multiple lesions with symptoms of Sigatoka that failed both direct isolation (conidia) and isolation based on ascospore discharge were subjected to direct extraction of DNA using the DNeasy Plant Mini Kit (Qiagen, Germany) according to the manufacturer's recommendation. One isolate per leaf was subjected to the PCR analysis using species-specific primers.

Species identification. Morphological characters. Four isolates from each region were arbitrarily chosen for the morphometric assessments and characterization. The conidia were transferred to microscope slides previously coated with $50 \%$ glycerin, and then observations were made under a light microscope. The morphological characters examined were: conidia (length and width), septation, basal hilum and conidial shape, and presence of sporodochia (34). The identification was derived from approximately 50 observations of conidia from each isolate within each region.

DNA extraction. DNA was extracted from every single-spore culture. Four mycelium plugs from colonies growing on V8 juice agar were transferred to $50 \mathrm{ml}$ of V8 broth $(250 \mathrm{ml}$ of V8 juice and $3 \mathrm{~g}$ of $\mathrm{CaCO}_{3}$ per liter of medium, $\mathrm{pH} 6.5$ ) in a $250-\mathrm{ml}$ flask and incubated for 10 days at $25^{\circ} \mathrm{C}$ and $120 \mathrm{rpm}$ in a shaker. The mycelium was then washed with sterile water and the excess water was removed using sterile filter paper. The mycelium was ground to powder using liquid nitrogen in a porcelain mortar and pestle. DNA was extracted using the cetyltrimethylammonium bromide (CTAB) method (13). An aliquot of $50 \mu \mathrm{l}$ of TE buffer $(10 \mathrm{mM}$ Tris-HCl and $1 \mathrm{mM}$ EDTA, $\mathrm{pH}$ 8.0) was added to each DNA sample. RNA was digested with RNase A for $2 \mathrm{~h}$ at $37^{\circ} \mathrm{C}$ before storage at $-20^{\circ} \mathrm{C}$. The concentration of DNA was quantified in a spectrophotometer (NanoDrop 2000 Thermo Scientific), and working solutions were standardized to $20 \eta \mathrm{g} / \mu \mathrm{l}$ of DNA.

Species-specific primers. The primer pairs ACTR/MFactF, MMactF2/MMactRb, and MEactR/ACTF specific for M. fijiensis, $M$. musicola, and $M$. eumusae, respectively, were used to identify each isolate. PCR conditions were as described by Arzanlou et al. (1), except that the DNA concentration used was $20 \eta \mathrm{g} / \mu \mathrm{l}$. All amplifications were performed in a thermal cycler MJ PTC-100 (Bio-Rad). After the PCR reaction, $5 \mu \mathrm{l}$ of each PCR product was subjected to electrophoresis in $2.0 \%$ agarose gel in $1 \times$ TBE and viewed under UV on gel stained with GelRed (Biotium). Fragments were compared with a 100-bp DNA ladder and scored. Amplification controls from known species were used in each gel to validate the results. Thus, the specific primer used to detect $M$. fijiensis was tested with DNA from naturally infected banana leaves collected in Manaus, Amazonas State, where BS is known to occur. The specific primer sets (ACTR/MFactF, MMactF2/ MMactRb, and MEactR/ACTF) were also used for DNA amplification from healthy banana leaves (controls). The primers MEactR/ACTF were not tested as a control due the absence of $M$. eumusae in Brazil, but were tested with DNA from leaf tissue with symptoms of yellow Sigatoka.

DNA phylogeny. Partial sequences of the internal transcribed spacer (ITS) region were PCR-amplified using fungal specific primer ITS1F (17) and the general primer ITS4 (38). PCR amplifications were done in $20-\mu \mathrm{l}$ reaction volumes containing $1 \times \mathrm{PCR}$ buffer (Invitrogen, Carlsbad, CA), $2.5 \mathrm{mM} \mathrm{MgCl}_{2}, 0.2 \mathrm{mM}$ each dNTP (Invitrogen), $0.375 \mathrm{mM}$ each primer, and $0.5 \mathrm{U}$ Taq polymerase (Invitrogen). Thermocycling conditions consisted of an initial melt at $94^{\circ} \mathrm{C}$ for $3 \mathrm{~min}$, followed by 30 cycles of $94^{\circ} \mathrm{C}(30$ s), $55^{\circ} \mathrm{C}(30 \mathrm{~s})$, and $72^{\circ} \mathrm{C}(1 \mathrm{~min})$, and a final hold of $72^{\circ} \mathrm{C}$ for 8 min. All amplifications were performed in a MyCycler thermocycler (Bio-Rad Laboratories Inc., Hercules, CA). For each PCR amplification, $5 \mu \mathrm{l}$ were subjected to electrophoresis in $1.8 \%$ agarose gels stained with SYBR Green I nucleic acid stain (Invitro- gen) and viewed with UV light. PCR products were cleaned with ExoSap-IT (USB, Cleveland, OH) following the manufacturer's instructions. Sequencing was performed at the Core Instrumentation Facility (CIF) of the University of California's (UC) Institute of Integrative Genome Biology at UC Riverside.

The nucleotide sequences were edited with Sequencher 4.6 (Gene Codes Corp., Ann Arbor, MI) and aligned using Clustal in MEGA 5.05 software (36). Two sets of alignments were made. One alignment contained all isolates obtained in the present survey, and the second contained only representative isolates of the present survey plus sequences of M. fijiensis (accession EU114250, AY266152, AF181705, EU514252), M. eumusae (AY923760, AY923759, AY923757, EU140340, GU168036), M. musicola (AY646473, AY646466, AY646505, AY646507), Pseudocercospora indonesiana (EU514283, EU514283), P. basiramifera (AF309595), $P$. paraguayensis (DQ267602), P. assamensis (EU514281), and P. longispora (EU5dias284, EU514285), which were downloaded from GenBank. The first set was used to estimate the number of haplotypes in the sample and the second set was used for phylogenetic inferences. Sequences of the second set were subjected to Bayesian phylogenetic analysis using MrBayes v.3 (33). Nucleotide substitution model was selected using MrModeltest v. 2.2 (27), and the HKY+I evolution model was used for the analysis. The Markov Chain Monte Carlo (MCMC) analysis of four chains started from a random tree topology and lasted 10,000,000 generations. Trees were saved at each 100 generations, resulting in 75,000 saved trees. Burn-in of $25 \%$ was made and posterior probabilities (PPs) were calculated. Maximum parsimony (MP) analysis was also conducted using the heuristic search option with 1,000 random-addition sequence replicates and tree bisection reconnection (TBR) branch swapping in PAUP* (4.0 beta 10) (35). Gaps were treated as missing data.

\section{Results}

Sampling and fungal isolation. A total of 800 samples of leaf tissue were examined, and most had typical symptoms of the yellow Sigatoka: elongated streaks, elliptical in shape, and chlorotic areas around the necrotic spots with dark brown borders, gray color center where regular lines of sporodochia could be seen (Fig. 2A to F). Symptoms of five samples collected in the Zona da Mata region were similar to those of BS, but no conidia of $M$. fijiensis were found (Fig. 2G and $\mathrm{H}$ ). No perithecia were observed in the samples. In total, 239 isolates were obtained from the four regions of Minas Gerais State (Table 1). Twenty-two isolates were obtained

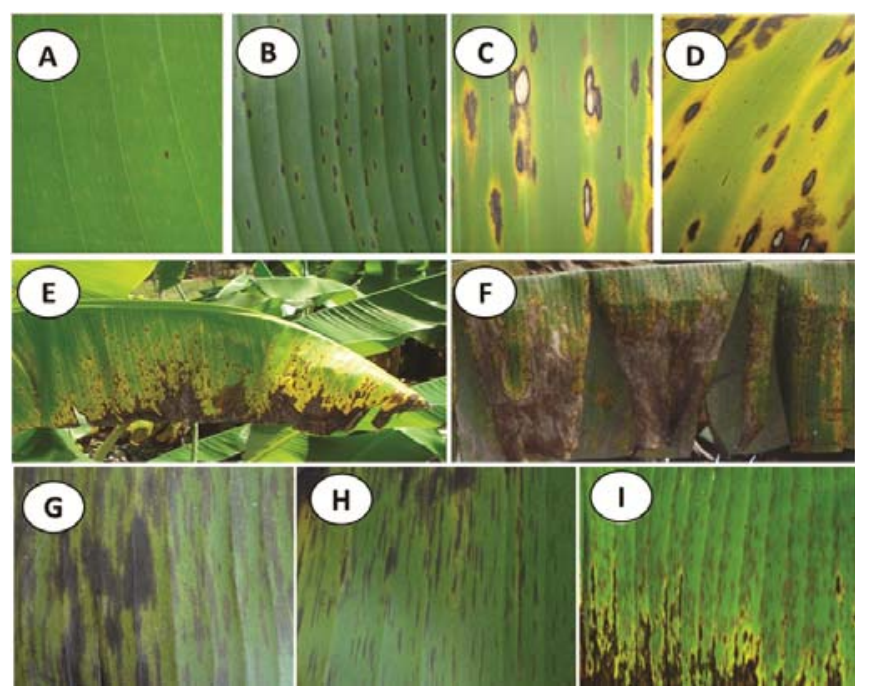

Fig. 2. Typical symptoms of yellow Sigatoka from samples of banana varieties from the AAB group collected in Minas Gerais State, Brazil (A to F). Symptoms similar to black Sigatoka observed in banana leaves (AAB group) collected in the Zona da Mata region of Minas Gerais State, Brazil ( $G$ and $\mathbf{H})$. Symptoms of black Sigatoka in a sample (AAB group) collected in Manaus, Amazonas State, Brazil (I). 
from the Triângulo Mineiro, 76 from the North, 80 from the South, and 61 from the Zona da Mata region.

Species identification. Morphological characters. Two hundred conidia of isolates obtained from the four regions (50 conidia/ region) were morphologically characterized. Conidia were typically cylindric to obclavate in shape, pale brown to olivaceous in color, 2-7 septa predominating 3-6, straight or curved, indistinct basal hilum and dimensions 30-70 × 3-5 $\mu \mathrm{m}$ (Table 2). Sporodochia were detected in the majority $(>90 \%)$ of leaf tissue samples with sporulating lesions, suggesting that most lesions were caused by $M$. musicola.

Species-specific PCR analysis. DNA of all isolates was PCRamplified with species-specific primers based on the partial sequence of the actin gene. The 200-bp amplicons were detected only for $M$. musicola-specific primers. No amplification with $M$. fijiensis-and M. eumusae-specific primers were observed.

ITS phylogeny and haplotype diversity. Seven haplotypes were identified based on the ITS sequences of 186 isolates (Table $3)$. Haplotype 1 was the most common haplotype $(n=161)$ and was detected in all sampling regions. Haplotype 2 consisted of seven individuals, three from the North and four from the Triângulo regions. Haplotype 3 consisted of two individuals from Zona da Mata, and haplotypes 4 and 5 had one individual from the Zona da Mata and South regions, respectively. Haplotype 6 had two individuals from the North and Triângulo regions. Haplotype 7 was the second most frequently found and consisted of 12 individuals, five from the Triângulo, four from the South, and three from the North. There was no obvious relationship between the isolates geographical origin and haplotype.

Results of BLAST analyses revealed that four out of seven haplotypes found in this study had also been identified in other countries: haplotype 1 has been identified in Saint Lucia, Martinique, Guadeloupe, Guinea, Cameroon, and Australia; haplotype 2 in Colombia; haplotype 6 in Australia; haplotype 7 in Australia, Venezuela, Martinique, Guadeloupe, Costa Rica, and Colombia. No sequences were found in GenBank that matched haplotypes 3, 4, and 5.

Thirty-three sequences were used in the phylogenetic analysis based on ITS which included representative haplotypes $(n=7)$ detected in this study and representative sequences downloaded from GenBank. A total of $486 \mathrm{bp}$ were subjected to the analyses.

The MP and Bayesian analyses produced identical trees, so only the Bayesian tree is presented (Fig. 3). Both analyses resulted in a tree with five well-supported clades. Clade I, IV, and V consisted of $P$. longispora, $M$. eumusae, and $M$. fijiensis and had bootstrap/posterior probability (PP) values of 96/0.94, 95/0.98, and 100/1.00, respectively. Members of M. musicola were divided into two clades with bootstrap/PP values of 97/0.92 and 100/1.00. The maximum parsimony analysis resulted in one tree with a length of
72, consistency index (CI) of 0.847 , and retention index (RI) of 0.971 .

\section{Discussion}

This study clearly established that only $M$. musicola is found in Minas Gerais State associated with banana. No isolates of $M$. fijiensis were detected based on our extensive survey, and therefore regulatory quarantine issues in this region with respect to $\mathrm{BS}$ should be revised. The establishment of BS in banana producing areas located in the tropical regions usually leads to severe crop losses. However, in Minas Gerais State, no changes in disease impact or in disease management practices occurred as a result of the report of BS by Castro et al. (8) and Ferrari et al. (14). Therefore, it is hypothesized that $M$. fijiensis did not establish in the state, either because the pathogen is not fully adapted to the environmental conditions of these areas or the first report of BS was not correct.

Studies in the Pacific Islands, Latin America, and Africa found that once $M$. fijiensis has been introduced into an area where $M$. musicola is present, M. musicola is rapidly displaced (6,39). However, in other places such as the Philippines and Vietnam, this has not occurred and $M$. musicola remained present after the appearance of BS $(6,22)$. Thus, the rate of displacement seems to be influenced by genetic and/or ecological factors (24). Unfortunately, we were not able to compare the aggressiveness between isolates of M. musicola and M. fijiensis because isolates of the latter species were not detected in the sampled fields.

If both species were distributed in the state of Minas Gerais at one point in time, it is likely that environmental conditions could have influenced the apparent dominance of M. musicola. For example, the co-existence and distribution of both species is apparently linked to humidity and temperature, which in turn is markedly influenced by altitude $(9,10,24,32)$. In two studies carried out to investigate the distribution of Mycosphaerella spp., M. musicola was the dominant species at high altitudes and M. fijiensis developed better at low altitudes $(26,32)$. The analyses of conidia germination, growth of germ tubes, incubation period, and life cycle of both $M$. fijiensis and M. musicola under different ecological conditions revealed that in a low altitude zone $(80 \mathrm{~m}$ elevation) with temperatures around 21 to $33^{\circ} \mathrm{C}$, both diseases were found in the area, but BS was dominant. On the other hand, in highland areas ( $>1,300 \mathrm{~m}$ elevation) with temperatures around 15 to $18^{\circ} \mathrm{C}, M$. musicola had a shorter incubation period than M. fijiensis and was more prevalent (26). Despite this, species prevalence according to altitude seems not to occur in all areas where both pathogens cooccur. In Colombia, both pathogens are equally severe at altitudes of 1,500 $\mathrm{m}(24)$, and low temperatures and high altitude are not limiting factors for $M$. fijiensis infections. Similarly, in Costa Rica, the pathogen has been detected affecting banana plants at 1,360 m.a.s.l. (1).

Table 2. Dimensions $(\mu \mathrm{m})$ and characteristics of Pseudocercopora musae conidia from different regions of Minas Gerais

\begin{tabular}{lccccc}
\hline Source & Length & Width & Number of septa & Basal hilum & Form \\
\hline Minas Gerais & $30-70($ mean 50.45) & $3-5($ mean 3.3) & $2-7$ (mostly 3-6) & Absent & Straight and curved \\
Meredith and Lawrence (1970) & $19-94($ mean 59) & $2.5-3.8($ mean 3.0) & $1-7$ (mostly 3-6) & Indistinct & Straight and curved \\
\hline
\end{tabular}

Table 3. Polymorphic site and indel positions in the sequence of the ribosomal DNA intergenic transcribed spacer (rDNA-ITS) region which differentiate the haplotypes of Mycosphaerella musicola

\begin{tabular}{|c|c|c|c|c|c|c|c|c|c|c|c|c|c|c|c|c|c|}
\hline \multirow[b]{2}{*}{ ITS haplotype } & \multirow[b]{2}{*}{ Occurrence } & \multicolumn{16}{|c|}{ Nucleotide position $(b p)^{a}$} \\
\hline & & 26 & 53 & 66 & 96 & 98 & 112 & 121 & 122 & 123 & 124 & 265 & 311 & 347 & 353 & 396 & 434 \\
\hline 1 & 161 & $\mathrm{~T}$ & $\mathrm{~A}$ & $\mathrm{G}$ & $\mathrm{C}$ & $\mathrm{C}$ & $\mathrm{G}$ & $\mathrm{T}$ & A & $\mathrm{C}$ & $\mathrm{G}$ & $\mathrm{T}$ & $\mathrm{G}$ & $\mathrm{T}$ & - & A & $\mathrm{C}$ \\
\hline 2 & 7 & $\mathrm{~T}$ & A & $\mathrm{G}$ & $\mathrm{C}$ & $\mathrm{C}$ & $\mathrm{G}$ & $\mathrm{T}$ & A & $\mathrm{T}$ & $\mathrm{G}$ & $\mathrm{T}$ & $\mathrm{G}$ & $\mathrm{T}$ & - & A & $\mathrm{C}$ \\
\hline 3 & 2 & $\mathrm{~T}$ & A & $\mathrm{G}$ & $\mathrm{C}$ & $\mathrm{C}$ & $\mathrm{G}$ & $\mathrm{G}$ & A & $\mathrm{C}$ & $\mathrm{G}$ & $\mathrm{T}$ & $\mathrm{G}$ & $\mathrm{T}$ & - & A & $\mathrm{C}$ \\
\hline 4 & 1 & $\mathrm{C}$ & A & $\mathrm{G}$ & $\mathrm{C}$ & $\mathrm{C}$ & $\mathrm{G}$ & $\mathrm{T}$ & A & $\mathrm{C}$ & $\mathrm{G}$ & $\mathrm{T}$ & $\mathrm{G}$ & $\mathrm{T}$ & - & A & $\mathrm{C}$ \\
\hline 5 & 1 & $\mathrm{~T}$ & $\mathrm{~A}$ & $\mathrm{G}$ & $\mathrm{C}$ & $\mathrm{C}$ & $\mathrm{G}$ & $\mathrm{T}$ & A & $\mathrm{C}$ & $\mathrm{G}$ & $\mathrm{C}$ & $\mathrm{G}$ & $\mathrm{T}$ & - & A & $\mathrm{C}$ \\
\hline 6 & 2 & $\mathrm{~T}$ & $\mathrm{~A}$ & $\mathrm{~A}$ & $\mathrm{~T}$ & $\mathrm{~A}$ & $\mathrm{G}$ & $\mathrm{T}$ & $\mathrm{T}$ & $\mathrm{C}$ & $\mathrm{C}$ & $\mathrm{T}$ & A & $\mathrm{C}$ & $\mathrm{C}$ & $\mathrm{G}$ & $\mathrm{T}$ \\
\hline 7 & 12 & $\mathrm{~T}$ & $\mathrm{G}$ & $\mathrm{A}$ & $\mathrm{T}$ & $\mathrm{A}$ & A & $\mathrm{T}$ & $\mathrm{T}$ & $\mathrm{C}$ & $\mathrm{C}$ & $\mathrm{T}$ & A & $\mathrm{C}$ & $\mathrm{C}$ & $\mathrm{G}$ & $\mathrm{T}$ \\
\hline
\end{tabular}

${ }^{a}$ Nucleotide position is relative to the end of the sequence CATTACCGAGTGAGGG present in the beginning of sequencing of rDNA-ITS region. 
The altitude and temperature conditions of Minas Gerais State where samples were collected vary considerably. The summer average maximum temperature and altitude ranges from $23.6^{\circ} \mathrm{C}$ and $1,276 \mathrm{~m}$, respectively, in the South of Minas Gerais to $31.5^{\circ} \mathrm{C}$ and $297 \mathrm{~m}$, respectively in the Zona da Mata. The average values of relative humidity in the South and Zona da Mata are suitable for BS. In these regions, the summer average relative humidity ranged from 71 to $87 \%$ in 2009 to 2011 (Table 4). Despite the favorable temperatures and suitable humidity conditions in the South and Zona da Mata, BS has not become widespread, and it currently is not regarded to be important to banana growers. It is important to emphasize that samplings were conducted in the summer when rainfall frequency and temperatures are favorable to the development of Sigatoka disease.

Sigatoka disease in bananas can be controlled with the application of fungicides and by planting resistant varieties (24). Protectant and systemic fungicides are regularly used in crops in North of Minas Gerais, but no chemical control is routinely used in plantations set in others regions. In the latter regions, bananas are grown on small farms usually located in hilly areas where topography hampers fungicide application. In Brazil, there are several resistant varieties to Sigatoka diseases; however, those that are commercially grown in Minas Gerais State, 'Nanica' (AAA) and 'Prata' (AAB), are very susceptible to both YS and BS (12). Therefore, in the area where BS was first detected, Zona da Mata-MG, a combination of susceptible varieties and no fungicide application, would have allowed for the establishment of the disease in large acreages.
Another intriguing aspect of the putative occurrence of BS in Minas Gerais is the restriction of the disease to the South and Zona da Mata regions. The North of Minas Gerais is the most important banana producing region and approximately 15,000 ha are cultivated (20). Although it is 600 to $750 \mathrm{~km}$ from other production areas, aerial dissemination to these places would be expected, since bananas are widely cultivated as a subsistence crop which could have contributed to the spread of the pathogen in "small jumps", mediated by the dispersal of airborne ascospores of M. fijiensis.

Another possible but unlikely explanation for the absence of $M$. fijiensis would be that the emergency control measures adopted when BS was reported for the first time were effective in preventing the spread of the recently detected pathogen. Technical guidance was provided to farmers and abandoned banana fields were destroyed as part of prevention to avoid the dispersal of the pathogen to other areas of the state. Nevertheless, considering the nature of an airborne pathogen having a broad availability of host population, this would not occur.

The symptoms of BS and yellow Sigatoka can be confused and vary depending on the cultivar and whether the plants have been treated with fungicides (18). We took samples containing different symptoms (specks, streak, and spot). But we observed the higher production of conidia at spot stage, characteristic of $M$. musicola (6). In the municipality of Piau, in the Zona da Mata region, where M. fijiensis was first reported (8), banana leaves with symptoms resembling those of BS were found. The diagnosis of BS was based on symptomatology and microscopic examinations of morphological characteristics of the asexual structures of the fungus

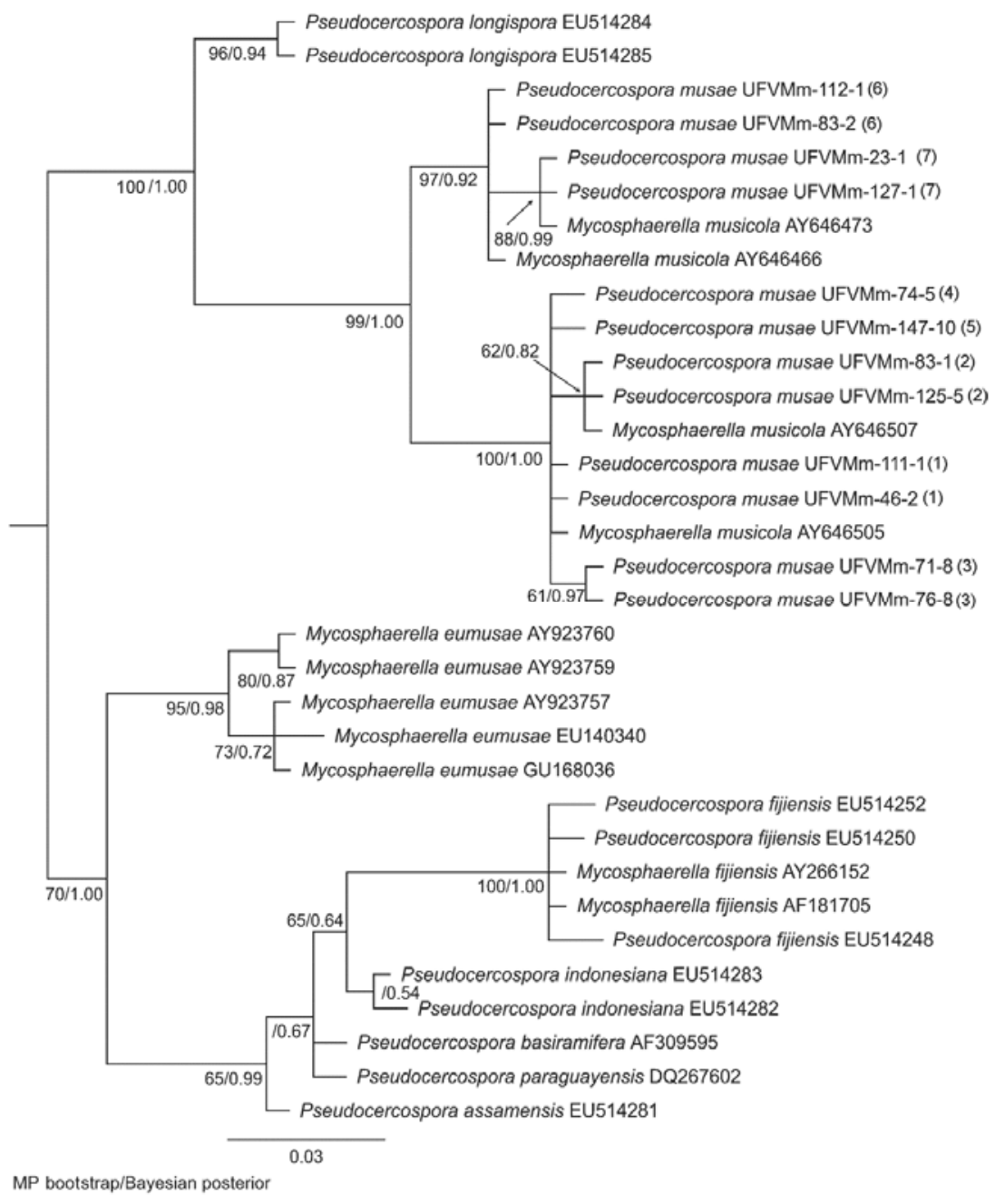

Fig. 3. The $50 \%$ majority rule tree of 75,000 trees from Bayesian phylogeny based on the internal transcribed spacer (ITS) sequence alignment of $P$ seudocercospora musae, the anamorph of Mycosphaerella musicola. Numbers at nodes indicate bootstrap support (>50\%) of maximum parsimony/Bayesian posterior probabilities. Scale bar shows 0.03 expected changes per site. Haplotypes (in brackets). 
Table 4. Average values of meteorological variables estimated for representative municipalities (in parentheses) located in four regions of Minas Gerais State in January, February, and March $^{\mathrm{a}}$

\begin{tabular}{|c|c|c|c|c|c|c|}
\hline \multirow[b]{2}{*}{ Region } & \multirow[b]{2}{*}{ Altitude (masl) } & \multirow[b]{2}{*}{ Year } & \multicolumn{2}{|c|}{ Temp. range $\left({ }^{\circ} \mathbf{C}\right)^{b}$} & \multirow[b]{2}{*}{$\mathbf{R H}(\%)^{\mathrm{c}}$} & \multirow{2}{*}{$\begin{array}{c}\text { Cumulative } \\
\text { precipitation }(\mathbf{m m})\end{array}$} \\
\hline & & & Min & Max & & \\
\hline \multirow[t]{3}{*}{ North (Jaíba) } & 460 & 2009 & 24.9 & 30.5 & 73 & 362 \\
\hline & & 2010 & 19.1 & 30.4 & 71 & 215 \\
\hline & & 2011 & 24.0 & 28.3 & 75 & 635 \\
\hline \multirow[t]{3}{*}{ South (Maria da Fé) } & 1,276 & 2009 & 13.5 & 23.6 & 87 & 795 \\
\hline & & 2010 & 13.5 & 23.9 & 84 & 549 \\
\hline & & 2011 & 14.7 & 23.8 & 85 & 952 \\
\hline \multirow[t]{3}{*}{ Zona da Mata (Muriaé) } & 297 & 2009 & 19.7 & 30.0 & 80 & 716 \\
\hline & & 2010 & 20.2 & 31.5 & 72 & 311 \\
\hline & & 2011 & 20.4 & 29.3 & 75 & 418 \\
\hline \multirow[t]{3}{*}{ Triângulo (Uberlândia) } & 869 & 2009 & 19.2 & 28.9 & 74 & 546 \\
\hline & & 2010 & 19.4 & 28.1 & 69 & 461 \\
\hline & & 2011 & 19.2 & 27.4 & 74 & 815 \\
\hline
\end{tabular}

a Source: Instituto Nacional de Meteorologia (INMET).

b Average minimum (Min) and maximum (Max) temperatures.

c Average relative humidity.

(8); but molecular tests did not confirm the presence of $M$. fijiensis. The combination of morphological and molecular data helped the identification of several species of Mycosphaerella occurring on banana (3). The latter approach was used in the present study, and we are confident that $M$. fijiensis was not present in the analyzed samples.

The nucleotide variation between the haplotypes in our study ranged between 1 and $11 \mathrm{bp}$. Similar results were found by Thomas-Hall et al. (37) in 2004, where phylogenetic analysis of the ITS region from 111 samples of Sigatoka disease revealed seven distinct clades with nucleotide variation ranging from 4 to 14 bp. The split of $M$. musicola sequences into two clades found in this study could suggest the occurrence of more than one closely related or cryptic species in Minas Gerais State, but additional analyses did not support this. For example, isolates with different haplotypes from both clades were scored for genetic variation using amplified fragment length polymorphism (AFLP), and all isolates produced very similar banding patterns, suggesting there was not enough genome-wide variation to support a speciation event. Additionally, three nuclear loci ( $\beta$-tubulin, Actin, and Elongation factor 1-alpha, EF-1 $\alpha$ ) and one mitochondrial locus (small subunit rDNA) were also sequenced from representative haplotypes which also did not provide evidence of cryptic species (data not shown). The analysis of other genomic regions combined with an assessment of genome-wide variation with microsatellite markers could help to elucidate this, and we are currently investing this.

This work showed that YS is the prevailing leaf spot disease of banana in the state of Minas Gerais. BS was not detected but more surveys need to be conducted on a regular basis in which thorough sampling procedures and genetic analyses are employed. This will help answer an important question that remains open: could the first report of the occurrence of BS have been related to the misidentification of the pathogen? If this is the case, regulatory/legislative control measures need to be revised, because the restrictions imposed by phytosanitary laws have been perverse to farms and the state's economy.

\section{Acknowledgments}

This work was supported by the Fundação de Amparo à Pesquisa do Estado de Minas Gerais - FAPEMIG. We thank the Coordenação de Aperfeiçoamento de Pessoal de Nível Superior (CAPES) and Conselho Nacional de Desenvolvimento Científico e Tecnológico (CNPq) for providing fellowships to L. I. S. Gomes. We thank Paulo Parizzi from Ministério da Agricultura for facilitating the location of BS occurrence in Minas Gerais State. Thanks to the Department of Plant Pathology, University of California, Riverside for providing the facilities for part of the work done by L. I. S Gomes and to the two anonymous reviewers for providing valuable comments.

\section{Literature Cited}

1. Arzanlou, M., Abeln, E., Kema, G., Waalwijk, C., Carlier, J., de Vries, I., Guzman, M., and Crous, P. W. 2007. Molecular diagnostics for the Sigatoka disease complex of banana. Phytopathology 97:1112-1118.

2. Arzanlou, M., Crous, P. W., and Zwiers, L. H. 2010. Evolutionary dynamics of mating-type loci of Mycosphaerella spp. occurring on banana. Eukaryotic Cell 9:164-172.

3. Arzanlou, M., Groenewald, J., Fullerton, R., Abeln, E., Carlier, J., Zapater, M., Buddenhagen, I., Viljoen, A., and Crous, P. W. 2008. Multiple gene genealogies and phenotypic characters differentiate several novel species of Mycosphaerella and related anamorphs on banana. Persoonia 20:19-37.

4. Balint-Kurti, P. J., May, G. D., and Churchill, A. C. L. 2001. Development of a transformation system for Mycosphaerella pathogens of banana: A tool for the study of host/pathogen interactions. FEMS Microbiol. Lett. 195:9-15.

5. Carlier, J., El Hadrami, A., Hayden, H., Zapatar, M. F., and Lapere, F. 1999. Populations study of Mycosphaerella fijienis and genetic improvement of bananas for resistance to black leaf streak disease. InfoMusa 8:16.

6. Carlier, J., Fouré, E., Gauhl, F., Jones, D. R., Lepoivre, P., Mourichon, X., Pasberg-Gauhl, C., and Romero, R. A. 1999. Black leaf streak. Pages 37-79 in: Diseases of Banana, Abacá and Enset. D. R. Jones, ed. CAB Publishing, Wallingford, UK

7. Carlier, J., Zapater, M. F., Lapeyre, F., Jones, D. R., and Mourichon, X. 2000. Septoria leaf spot of banana: A newly discovered disease caused by Mycosphaerella eumusae (Anamorph Septoria eumusae). Phytopathology 90:884-890.

8. Castro, M. E. A., Pereira, J. C. R., and Gasparotto, L. 2005. First report of black-sigatoka in the State of Minas Gerais, Brazil. Fitopatol. Bras. 30:668.

9. Churchill, A. C. L. 2011. Mycosphaerella fijiensis, the black leaf streak pathogen of banana: Progress towards understanding pathogen biology and detection, disease development, and the challenges of control. Mol. Plant Pathol. 12:307-328.

10. Cintra, W. J., Valadares, R., Avelino, R. C., Bucker, W. M., Xavier, F. R. V., Ramos, A. F., and Anderson, P. P. 2008. Worldwide geographical distribution of Black Sigatoka for banana: Predictions based on climate change models. Sci. Agric. 65:40-53.

11. Crous, P. W., and Mourichon, X. 2002. Mycosphaerella eumusae and its anamorph Pseudocercospora eumusae spp. nov.: Causal agent of eumusae leaf spot disease of banana. Sydowia 54:35-43.

12. Dias, M. S. C. 2008. Doenças da bananeira. Pages 47-48 in: Informe agropecuário: Bananicultura irrigada: Inovações tecnológicas, Vol. 29. EPAMIG, Belo Horizonte, Brazil.

13. Doyle, J. J., and Doyle, J. L. 1990. Isolation of plant DNA from fresh tissue Focus 12:13-15.

14. Ferrari, J. T., Harakava, R., Nogueira, E. M. de C., and Castro, M. E. A. 2005. Ocorrência de sigatoka-negra da bananeira no Sul de Minas Gerais. Sum. Phytopathol. 31:34.

15. Fortune, M. P., Gosine, S., Chow, S., Dilbar, A., Hill, A. S., Gibbs, H., and Rambaran, N. 2005. First report of black Sigatoka disease (causal agent Mycosphaerella fijiensis ) from Trinidad. Plant Pathol. 54:246.

16. Frederick, R. D., Snyder, C. L., Peterson, G. L., and Bonde, M. R. 2002. Polymerase chain reaction assays for the detection and discrimination of the soybean rust pathogens Phakopsora pachyrhizi and P. meibomiae. Phytopathology 92:217-222.

17. Gardes, M., and Bruns, T. D. 1993. ITS primers with enhanced specificity for basidiomycetes application to the identification of mycorrhizae and rusts. Mol. Ecol. 2:113-118.

18. Gasparotto, L., Pereira, J. C. R., Hanada, R. E., and Montarroyos, A. V. V. 2006. Sigatoka-negra da bananeira. Embrapa Amazônia Ocidental, Manaus, Brazil.

19. Hanada, R. E., Gasparotto, L., Resende, J. C. P., and Sedoguchi, E. T. 2007. Panorama atual da sigatoka-negra da bananeira no Brasil. Fitopatol. Bras. 32:159. 
20. IBGE-Estados-Lavoura Permanente. 2011. 01 October 2013 from http:// www.ibge.gov.br/estadosat/temas.php?sigla $=m g \&$ tema=lavourapermanen te2011/

21. Johanson, A., and Jeger, M. J. 1993. Use of PCR for detection of Mycosphaerella fijiensis and $M$. musicola, the causal agents of Sigatoka leaf spots in banana and plantain. Mycol. Res. 97:670-674.

22. Jones, D. R. 2003. The distribution and importance of the Mycosphaerella leaf spot diseases of banana. Pages 25-41 in: Mycosphaerella Leaf Spot Diseases of Bananas: Present Status and Outlook. Proc. Workshop Mycosphaerella Leaf Spot Dis. L. Jacome, P. Lepoivre, D. Marin, R. Oriz, R. Romero, and J. V. Escalant, eds. The International Network for the Improvement of Banana and Plantain, Montpellier, France.

23. Maciel, G. A. 2006. Instrução Normativa $\mathrm{N}^{\circ}-289$, de 20 de outubro de 2006. Retrieved 12 January 2012 from http://www.in.gov.br

24. Marín, D. H., Romero, R. A., Guzmán, M., and Sutton, T. B. 2003. Black Sigatoka: An increasing threat to banana cultivation. Plant Dis. 87:208-222.

25. Meredith, D. S., and Lawrence, J. S. 1969. Black leaf streak disease of banana (Mycosphaerella fijiensis): Symptoms of disease in Hawaii, and notes on the conidial state of the causal fungus. Trans. Br. Mycol. Soc. 52:459-476.

26. Mouliom-Pefoura, A., Lassoudière, A., Foko, J., and Fontem, D. A. 1996. Comparison of development of Mycosphaerella fijiensis and Mycosphaerella musicola on banana and plantain in the various ecological zones in Cameroon. Plant Dis. 80:950-954.

27. Nylander, J. A. A. 2004. MrModeltest v2. Program distributed by the author. Evolutionary Biology Centre, Uppsala University, Sweden.

28. Pereira, J. C. R., Gasparotto, L., Coelho, A. F. S., and Urben, A. F. 1998. Ocorrência da Sigatoka negra no Brasil. Fitopatol. Bras. 23:295.

29. Ploetz, R. C. 2004. First report of Black Sigatoka of banana caused by Mycosphaerella fijiensis on Grand Bahama Island. Plant Dis. 88:772.

30. Rhodes, P. L. 1964. A new banana disease in Fiji. Commonw. Phytopathol.
News 10:38-41

31. Romero, R. A. 2003. The spread, detection and impact of black leaf streak disease and other Mycosphaerella species in the 1990s. Pages 21-24 in: Mycosphaerella Leaf Spot Diseases of Bananas: Present Status and Outlook. Proc. Workshop Mycosphaerella Leaf Spot Diseases. L. Jacome, P. Lepoivre, D. Marin, R. Ortiz, R. Romero, and J. V. Escalant, eds. The International Network for the Improvement of Banana and Plantain, Montpellier, France.

32. Romero, R. A., and Gauhl, F. 1988. Efectos de la Sigatoka en las plantas de banano a diferentes altitudes sobre el nivel del mar. Rev. ASBANA 12:7-10.

33. Ronquist, F., and Huelsenbeck, J. P. 2003. MrBayes 3: Bayesian phylogenetic inference under mixed models. Bioinformatics 19:1572-1574.

34. Stover, R. H. 1972. Banana, Plantain and Abaca diseases. Commonwealth Mycological Institute, Kew, Surrey, UK.

35. Swofford, D. L. 2002. Paup*: Phylogenetic analysis using parsimony (* and other methods). Sinauer Associates, Sunderland, MA

36. Tamura, K., Peterson, D., Peterson, N., Stecher, G., Nei, M., and Kumar, S 2011. MEGA5: Molecular evolutionary genetics analysis using maximum likelihood, evolutionary distance, and maximum parsimony methods. Mol. Biol. Evol. 28:2731-2739.

37. Thomas-Hall, S., Porchum, S., Henderson, J., Pattemore, J., and Aitken, E. 2004. Phylogenetic diversity of Mycosphaerella leaf spot disease. 1st Int Musa Congr., Penang, Malaysia.

38. White, T. J., Bruns, T., Lee, S., and Taylor, J. 1990. Amplification and direct sequencing of fungal ribosomal RNA genes for phylogenetics. Pages 315322 in: PCR Protocols: A Guide to Methods and Applications. M. A. Innis, D. H. Gelfand, J. J. Sninsky, and T. J. White, eds. Academic Press, San Diego.

39. Zandjanakou-Tachin, M., Vroh-Bi, I., Ojiambo, P., Tenkouano, A., Gumedzoe, Y., and Bandyopadhyay, R. 2009. Identification and genetic diversity of Mycosphaerella species on banana and plantain in Nigeria. Plan Pathol. 58:536-546. 